\title{
Real Vegan Cheese and the Artistic Critique of Biotechnology
}

\author{
REBECCA WILBANKS \\ STANFORD UNIVERSITY
}

\begin{abstract}
Drawing on the case study of Real Vegan Cheese (RVC), a synthetic biology project housed in a community lab or "biohackerspace," I argue that biohacking performs an "artistic critique" of the bioeconomy. Following Boltanski and Chiapello's use of the term, the "artistic critique" pits values of autonomy and creativity against a view of capitalist production as standardized and alienating, represented (in the case of biotechnology) by Monsanto's monoculture GMOs. In this way, biohacking is depicted as liberating biotechnology from the constraints of corporate and academic institutions. Through the use of design fiction and a playful aesthetic, projects such as RVC demonstrate a more legitimate-with respect to the values of the artistic critique-mode of production for a new generation of biotechnology products, one that is portrayed as driven primarily by ethical and aesthetic values rather than the profit motive. This analysis highlights the role that aesthetic and affective strategies play in advancing particular sociotechnical visions, and the way that biohacking projects operate in symbiosis with incumbent institutions even as they define themselves in opposition to them. Finally, it suggests that biohacking has certain limitations when considered as a form of public engagement with science.
\end{abstract}

\section{Keywords}

DIYbio; hacking; synthetic biology; design fiction; scientific authority; public engagement

\section{Introduction}

In Oryx and Crake, Margaret Atwood's 2003 satire of the bioeconomy, a team of enterprising students at the science and technology-focused Watson and Crick Academy invent ChickieNobs: a lab-grown meat product that, before it reaches the consumer as a deep-fried Bucket o'Nubbins, grows as a gaping maw of avian flesh haloed with numerous outgrowths of legs or wings. This revolting portrayal of lab-grown meat is linked to the way in which this innovation represents, in the novel, an intensification and exaggeration of an industrial system of food production that seeks to maximize efficiency and profit at any cost. ChickieNobs join a host of other branded

'Rebecca Wilbanks, Email: rrw@stanford.edu

Copyright (C) 2017 (Rebecca Wilbanks). Licensed under the Creative Commons Attribution Non-commercial No Derivatives (by-nc-nd). Available at estsjournal.org. 
foods and pharmaceuticals that collectively depict an out-of-control corporate oligarchy in which the actual health and well-being of people, animals, and the environment do not appear on the agenda. The novel paints a grim picture of biotechnology as a tool of large corporations (and that's before things go from dystopian to apocalyptic).

In 2014, I joined a group of biohackers in the San Francisco Bay Area working on a synthetic biology project to make "Real Vegan Cheese" in the lab, by genetically engineering yeast to produce milk proteins. Two years later, work on the project continues, but the most significant output of the project to date is Real Vegan Cheese (RVC) as a design fiction. RVC may be incarnated at some future point, but its imaginary avatar has already done significant work in the present, serving as a seed around which future scenarios crystallized and various Bay Area networks converged, attracting media interest from several continents, and eliciting interest from Silicon Valley's investment infrastructure. My choice to begin this article with a fictional reference is intended to highlight the point that for all the emphasis on hands-on activity, the tinkering associated with biohacking projects such as RVC can play a tactical role in efforts to define and advance broader sociotechnical imaginaries. Like Atwood's ChickieNobs, RVC is an imaginary product; but unlike ChickieNobs, it is a fiction that is intended to stand against the dystopian future of corporate control that the products in Atwood's novel evoke.

The phenomena of biohacking and DIYbio, ${ }^{2}$ which include efforts to open up the tools of biotechnology and molecular biology to those without formal training in the field, has been framed through the lens of legitimacy (Kelty 2010), a theme that was evident (although not exhausted) in early discussions about the safety and security of home or garage synthetic biology practices. The development of communal spaces--known as community labs or biohackerspaces-for individuals to pursue scientific or biotechnological projects is in part a response to concerns about the legitimacy of DIYbio, since these spaces develop safety guidelines and allow the community (sometimes in collaboration with established authorities such as the FBI) to informally police each other (Landrain et al. 2013, 12; Tocchetti and Aguiton 2015).

Yet as the dystopian setting of Oryx and Crake demonstrates, the institutions that make up "Big Bio" have faced legitimacy concerns of their own. Big Bio here refers to the more established (in comparison with biohackerspaces) organizations that make up the field of biotechnology: biotechnology firms, as well as the universities and public research institutions that, increasingly, operate alongside those firms in a single "heterarchical field" (Vallas and Kleinman 2008). The biohackerspace defines itself as "other than" these institutions, if not necessarily against them. In particular, Monsanto, as a large and unpopular biotechnology corporation, serves as a foil for what the biohackerspace, and RVC project, is not. The project follows the logic articulated by Freeman Dyson, a physicist and futurist aptly described as the patron saint of biohacking (Wohlsen 2011), in his 2007 article "Our Biotech Future": "the public distrusts Monsanto because Monsanto likes to put genes for poisonous pesticides into food crops, just as we distrusted von

2 Both terms were used by RVC participants to describe their activities, but biohacking and biohacker were more common, reflecting a desire to connect to the hacker tradition. In addition, DIYbio has a hobbyist and amateur connotation, whereas biohacking, like RVC itself, bridges recreational practices, startup culture, and certain academic approaches to synthetic biology. 
Neumann because he liked to use his computer for designing hydrogen bombs secretly at midnight. It is likely that genetic engineering will remain unpopular and controversial so long as it remains a centralized activity in the hands of large corporations" (n.p.).

Monsanto has been a target of protest since the 1990s, in part because of the "Terminator" sterile seed technology, which was patented but never brought to market (Jasanoff 2003, 237). Protests have continued in recent years, including a recent annual "March Against Monsanto" that began in 2013 and that year had participating rallies in 436 cities and 52 different countries (Upton 2013). Regardless of whether these kinds of protests represent a minority viewpoint or a wider legitimacy crisis in the field and a real threat to the development of a new generation of biotechnology products, ${ }^{3}$ this paper argues that biohacking can be understood as an effort to create a more legitimate system of biotechnological production. As projects such as RVC seek to demonstrate (Delgado and Callén 2016) a more legitimate method of production for a new generation of biotechnology products, they simultaneously perform an "artistic critique" of the bioeconomy. My use of "artistic critique" is borrowed from Boltanski and Chiapello (2005), for whom the "artistic critique" originating in avant-garde art movements pits values of autonomy and creativity against a view of capitalist production as standardized and alienating; the artistic critique of the bioeconomy imagines a playful, creative, and decentralized biotechnology practice juxtaposed against Monsanto's monoculture GMOs and a portrayal of academia as rigid, hierarchical, and increasingly utilitarian. My use of "artistic critique" highlights not only how certain values, particularly that of autonomy, frame decision making processes in the biohackerspace, but also underlines the role of aesthetics and affect (here, pleasure, fun, and whimsy) in advancing particular sociotechnical imaginaries. The artistic critique sits, sometimes uneasily, alongside other modes of legitimation, such as the ethical critique that RVC advances against animal agriculture, and the social critique of injustice and inequality that informs the background of the project.

Although the artistic critique is directed against the more established institutions of "Big Bio" (universities, large biotech corporations, etc.), it serves as a means of both distinction and connection with those institutions as actors from within these institutions deploy similar rhetorical strategies in support of a vision of distributed biotech innovation (in line with Boltanski and Chiapello's argument that the incorporation of the artistic critique became a major source of capitalism's legitimacy in the late twentieth century). While many have noted DIYbio's dependence on Big Bio, this discussion highlights the ways in which the relationship is more symbiotic than parasitic.

My analysis is distinguished by an in-depth focus on one project on which I spent over two years as a participant-observer. RVC is a collaboration between two Bay Area biohackerspaces: BioCurious in Sunnyvale, and Counter Culture Labs (CCL) in Oakland. Participants on the project include, with significant overlap between categories: committed vegans, stay-at-home moms with science PhDs, tech employees, punks, students from middle school to the graduate level, working scientists, an occasional drop-in retiree and more than

${ }^{3}$ Marris (2014) argues that there is little evidence that the public is afraid of synthetic biology. 
occasional drop-in journalist or film-maker, and a full-time (for at least part of the project) hacker. Two members had worked in the labs of two prominent academic synthetic biologists. Personal motivations for working on the project include promoting veganism by creating more attractive dairy alternatives; building the science/ DIYbio movement; positively impacting the public conversation about genetic engineering and synthetic biology through the creation of a new application; and the more immediate rewards of "meeting like-minded people and building a community," teaching and mentoring others, and gaining skills and experience with possible professional value. The project was also motivated by the desire to find a suitable project to take to iGEM, the International Genetically Engineered Machine competition that has played a key role in establishing synthetic biology as both an academic discipline and a target of corporate research and investment; the competition had just debuted a new track for "community labs."

This paper gives an account of biohacking that is strongly situated in the Bay Area; given the wealth of resources and institutions that support science, technology, and innovation here, the project undoubtedly would have developed differently in a different setting. At the same time, developments in this region may play an outsize role for "transnational cultures that orient toward Silicon Valley for models of social change" (Irani 2015, 3). My extended involvement with the project revealed the dense connections between the biohacking community in the Bay Area and other actors and institutions, including those from which the biohackerspace differentiates itself. These observed connections inform my analysis; for example, I include quotes from presentations at an annual synthetic biology industry conference because many RVC members were regular attendees there.

Projects in the biohackerspace progress as participants share their own skillset with the group, on the principle that everyone is an expert at something. At some points, I saw an opportunity to make a contribution based on my STS background (for example, leading discussions on the "social and ethical dimensions" of the project, and putting the goals of the project in dialogue with relevant STS scholarship as part of the team's iGEM presentation). Most of the time, my participation consisted of regular engagement with the mundane tasks of a volunteer-based enterprise: attending meetings, following listserv discussions, and helping to mail out thank-you gifts to people who contributed to the project's fundraising campaign. I find the anthropological notion of "collaboration" to be helpful in framing the other members not as "informants" but as partners in intellectual inquiry (Rappaport 2008), with both an intellectual and a personal interest in the developing social form of the biohackerspace. At the same time, both collaboration and participant-observation as research methods include the risk of complicity. As other social scientists in the field of synthetic biology have observed, the researcher's position as the "social" expert may help legitimize research endeavors (Calvert 2013). My own subject position is thus entangled in the legitimating processes I describe below.

\section{Scientific Authority and the Legitimizing Power of Publics}

I use the term legitimacy to signify something deeper and more structural than might be suggested by alternative formulations, such as "rebranding" biotechnology. While participants 
on the project did want to change the public perception of GMOs, they wanted to do so by demonstrating an alternative method of producing biotechnology that responded both to their own concerns and the concerns they perceived "the public" to have. The biohackerspace is thus an attempt to construct a "form of life" (Helmreich 2009, 6) that stands in contrast to the form of life represented by large biotech corporations and other institutions that contribute to the development of biotechnology. At the same time, it is possible that biohacking projects could contribute to a rebranding of biotechnology at large, without effecting much structural change on larger scales.

A broad definition of legitimacy is "a generalized perception or assumption that the actions of an entity are desirable, proper, appropriate within some socially constructed system of norms, values, beliefs, and definitions" (Suchman 1995, 57). It is an inherently interpersonal phenomenon, implying not only the ability to act but also social sanction of one's actions. In the 1970s, some scientists and social commentators began to worry that science was experiencing a legitimacy crisis (Schmandt 1971), although others noted that the evidence pointed to a growing ambivalence with, rather than rejection of, science, as the intertwinement of science with other domains such as industry and the military led to new problems and risks as well as benefits (Etzioni and Nunn 1974; Rip 1986; Knorr Cetina 1984). Post-WWII, policy documents such as Vannevar Bush's Science, The Endless Frontier presented a "linear model" of science and society relations, in which the free and curiosity-driven inquiry of scientists leads to objective knowledge claims that could separately be applied to spur social and economic progress. From the 1970s on, the accuracy of this model was challenged both by scholars (i.e., Stokes 1997) and by activist movements encompassing both scientists and non-scientists that queried the boundaries of scientific expertise and questioned the primacy of scientific authority in sociotechnical decisionmaking (Collins and Evans 2002, 239). STS scholarship asked "how to bring knowledgeable publics into the front-end of scientific and technological production" (Jasanoff 2003, 235).

At the same time, substantive changes in the structure of scientific research complicated Bush's linear model, as research in many fields became more tightly embedded in the market and more accountable to impacts and outcomes beyond peer review (Nowotny et al. 2003; Ziman 2000; Etzkowitz 2003). Synthetic biology, which emerged around the turn of the millennium as an ambitious re-conceptualization of genetic engineering, exemplifies these trends, engaging science and technology, academia and industry. In fields like synthetic biology, public engagement plays an increasingly important role in the legitimation of research agendas (Irwin 2006; Thorpe and Gregory 2010). Kelty and Panofsky go further, writing, "in recent decades, public participation has lost much of its adversarial edge to become a key, legitimating idiom of institutions across the spectrum of society $(2014,2)$.

In this context, parsing the construction of the "public" has become as critical for STS scholarship as attending to the construction of "science." Recent work investigates "perceptions of perceptions" and "imaginaries of the public"--that is, how scientists and policymakers perceive the public - finding that in synthetic biology and other developing fields, scientists and policymakers cast the public as a threat to scientific progress and associated economic growth (Welsh and Wynne 2013; Marris 2015). In addition, recent work integrating social movement 
studies with STS critiques the model of the "lay individual" public that underlies both previous STS scholarship and efforts by scientists and policy makers to address public perception. In contrast to the idea that the public consists of disinterested individuals whose opinions can be aggregated to get a measure of public opinion, scholars have shown how public opinion can instead be framed as the result of contestations between different "mobilized publics," groups that hold particular, collective visions of what constitutes the public good and act to advance their vision (Hess 2016 9-11). Also arguing implicitly against the notion of the lay individual public, Kelty (2013) uses the term "organized public" (following Warner 2002) to refer to a public that comes into being when addressed, often through campaigns carried out by formal social enterprises. Whereas previous discussions of public opinion often excluded social movements and organizations, this body of research analyzes their connections to broader public sentiment.

In line with Kelty's description of "coupling" between formal social enterprises and organized publics, RVC consists of an incorporated non-profit and a larger web of more transient and weakly engaged affiliations formed through platforms such as Meetup.com, Indiegogo, social media, and Google groups. By addressing the public through these and other media channels, RVC and other DIYbio groups seek to mobilize support for a vision of biotechnology as a decentralized and creative practice that is open to all. This vision is closely connected to what Stephen Hilgartner $(2015,36)$ describes as the "vanguard vision" of the BioBricks group in synthetic biology, which has been influential in drawing attention to synthetic biology as a whole. Sociotechnical vanguards "formulate and act intentionally to realize particular sociotechnical visions of the future that have yet to be accepted by wider collectives, such as the nation" (34). By focusing on how this vision of accessible biotechnology was interpreted in different ways as the details of the project were worked out, my analysis underscores the diversity of viewpoints and agendas comprised within this vision rather than its unity.

RVC's effort to mobilize a public in support of this vision is partly inspired by the sense that public sentiment constitutes a potential threat to the development of new fields like synthetic biology. It responds to the way in which biotechnology and biomedical research have been sites of contention over the role of the university and its ability to act in the "public interest" (Krimsky 2004; Winickoff 2013). Against this background of commercialized science, the RVC project highlights its participation in "open science" and its non-profit nature, framing its actions as undertaken with "public benefit" in mind. These appeals were not just meant to obtain support for RVC, but to contribute to a more positive view of genetic engineering in general. For example, a description of the project written for a hacker conference reads, "By being a not for profit group releasing our work in real time and aiming to reduce our environmental impact we avoid the tainted image of GMOs which are tied to huge multinational corporations. We are therefore in a strong position to argue that GMOs are beneficial to humanity." Members commonly cited changing the public perspective on GMOs as one motivation for the project.

However, while RVC emphasized its non-profit motivations, it is a particular kind of forprofit bogeyman--the large corporation--that serves as biohacking's most powerful foil. Concerns about corporate monopoly in synthetic biology have been voiced by both critics (http://www.etcgroup.org/issues/corporate-monopolies) and enthusiasts (Dyson 2007) of the 
field. RVC aims to be everything that Monsanto, in this discourse, is not. Where Monsanto represents the centralization of biotechnology, biohacking embodies a bevy of d-words-"distributed," "decentralized," "democratized," and "domesticated"—associated with putting technology in the hands of individuals and small groups. Where the invocation of Monsanto evokes secrecy and proprietary research, biohacking espouses openness, in that projects are transparently run and often allow anyone to join, and in the sense that they make data and results freely available.

Although RVC's claims to be working for the public good were initially tied to its nonprofit nature, as the project progressed and participants discussed what it would take to bring RVC to supermarket shelves, it became clear that the artistic critique is also compatible with forprofit strategies. While RVC members contemplated creating a start-up company, larger players in the biotech industry used similar rhetoric to describe their operations. For example, in a keynote speech at the SynBioBeta biotech industry conference in 2015, the CEO of Intrexon, Randal Kirk, positioned his company's "innovative" and putatively more ethical capitalism against "incumbent capitalism," stressing the decentralized nature of the former. Intrexon is a parent company that has bought many synthetic biology startups, creating a conglomerate. Kirk's description of his company as decentralized--he told the audience that Intrexon has no corporate headquarters--shows that in the business world, this term can refer to distributed work practices that go hand in hand with the consolidation of capital.

This presentation of biohacking as rhetorically opposed to a certain vision of the large corporation in particular corresponds to what Boltanski and Chiapello term the "artistic critique" of capitalism.

\section{Biohacking as Artistic Critique of Biotechnology}

Boltanski and Chiapello (2005) argue that capitalism finds legitimacy by incorporating critique into its operations. Since 1980, they argue that the "spirit of capitalism," or the normative framework that justifies people's participation in capitalist operations, is derived from a critique of capitalism that they term "artistic," because of its association with bohemian circles and a counter-cultural lifestyle:

This critique foregrounds the loss of meaning and, in particular, the loss of the sense of what is beautiful and valuable, which derives from standardization and generalized commodification, affecting not only everyday objects but also artworks (the cultural mercantilism of the bourgeoisie) and human beings. It stresses the objective impulse of capitalism and bourgeois society to regiment and dominate human beings, and subject them to work that it prescribes for the purpose of profit, while hypocritically invoking morality. To this it counterposes the freedom of artists, their rejection of any contamination of aesthetics by ethics, their refusal of any form of subjection in time and space and, in its extreme forms, of any kind of work. (38) 
The "artistic critique" of capitalism's alienating effects was successfully incorporated into the network capitalism that emerged in post-industrial societies, so that capitalist processes were seen by many as liberating rather than stultifying individual creativity. While Boltanski and Chiapello show that business texts began to promote networked, decentralized, and projectbased forms of organization while criticizing bureaucratic and authoritarian structures, they do not address the role of information technology in this evolution of business practices and rhetorics. Turner's 2006 history of Stewart Brand and the Whole Earth network shows how Brand and other actors created an association between the networked discourse of information technology and the values of creativity and autonomy that Boltanski and Chiapello impute to the artistic critique of capitalism. Central to this discourse is a particular figuration of the hacker, which carries the values of the artistic critique in its playful resistance to structures of authority. Brand's efforts helped to establish the hacker as half of a binary opposition: prankster vs. suit, free play vs. hierarchical authority. Thus, the values associated with one strain of the counterculture became associated with information technology and the networked style of capitalism that co-evolved with it.

While Boltanski and Chiapello's argument suggests that these values help to legitimate contemporary capitalism, Kohlenberger (2015) argues that similar values-which she relates to a particular kind of "cool" affect-have become a means of legitimating science in contemporary society. Although her analysis does not fully develop how this "aesthetic and affective" legitimation works (13), her descriptions of hackers and the cool scientists follow Boltanski and Chiapello's artist as rebellious figures, following non-utilitarian and seemingly more authentic and pure motivations. While Kohlenberger's work is focused on fictional representations of science and technology in popular culture, both biohacking and synthetic biology in some of its institutionalized forms are also marked by a geeky-cool aesthetic. Adopting the label of "hacking," with reference to the tradition highlighted by Turner, frames projects as a matter of pleasure and play driven by visionaries aiming to make a difference in the world rather than corporate or bureaucratic priorities: a widely cited definition of hacker is "a person who enjoys exploring the details of programmable systems and how to stretch their capabilities" (http://www.catb.org/jargon/html/H/hacker.html). Biohacking is thus portrayed as more human, and less alienating, than biotechnology practices associated with corporate or academic institutions-even when it takes place within those institutions.

Terms such as "hacking life" or "hacking DNA" are particularly prevalent in media accounts of synthetic biology; a 2014 PBS documentary concluded that synthetic biology is simply "a formal term for biohacking." In this usage of the term, biohacking is defined through the orientation one takes towards life and the means of manipulating it, more than the social

"This argument depends on a conflation of science and technology common in depictions of "cool science." (Think of the quip of Matt Damon's character in the 2015 film The Martian when he finds himself left for dead by his crew and alone on Mars: "I'm going to have to science the shit out of this." He then survives for the next two years by performing an impressive series of hacks using the left-behind equipment). Similarly, projects such as RVC that are application-driven rather than basic research are still often described as "open science" or "citizen science" projects; the implications of this conflation in legitimizing projects and research agendas are further discussed in the final section. 
position of the biohacker subject, who could be a professor or an industry scientist. Founding members of synthetic biology have longstanding or recently cultivated ties to the world of hacking; Tom Knight numbers among Steven Levy's Hackers: Heroes of the Computer Revolution, while Drew Endy was trained as an engineer and presented a talk entitled "Programming DNA" at the 2008 Chaos Communication Congress (an important hacker conference). Bernadette Bensaude Vincent (2016) argues that synthetic biology changes the "moral economy" of scientific practice, "from the sober self-dedication of disinterested scientists to a playful activity of creating toys" (93).

Yet if the idea of biohacking as creative play can be found in academic approaches to synthetic biology, it is expressed even more fully in the biohackerspace. Josiah Zayner, a contributor to CCL projects, founder of a biohacking supply company that produces kits for home experimentation, and subject of numerous media profiles for, among other things, dramatic self-experimentation, forcefully articulates biohacking as a species of artistic critique. Zayner holds a PhD from the University of Chicago and worked as a postdoctoral fellow at NASA, but left the academic track to pursue biohacking. Like several RVC members, he favors punk attire and can often be seen wearing a t-shirt that bears the slogan of his company: "create something beautiful." In a variation of the bohemian artists from whom Boltanski and Chiapello take their inspiration, here the "refusal of subjection in any form" is less about the pursuit of artistic-or scientific-truth, and more about "build[ing] something cool," with the added suggestion that biohacking could help save the world. "Are people dying and suffering needlessly because of all these committees and all these rules? And what if people just say, 'F- you, I'm going to do it anyway'? And what if people start getting cured?" (Weissmueller 2016).

Zayner represents the most radical end of biohacking's artistic critique. Yet his central message - that biotechnology should be liberated from bureaucratic and centralized structures in order to promote creative practices and do good in the world--accords with that of other biohacking groups. CCL's fundraising website writes, "for far too long, science has been locked away in the 'ivory towers' of universities and research labs" (https: / / www.kickstarter.com / projects / 1836537355/ counter-culture-labs-your-biohacking-andcitizen-s/description), and one CCL member is quoted in a press release about CCL's funding campaign: "we want this to be a place where people can be playful about discovery and exploration. Science doesn't have to be only for the experts." These quotes suggest that the biohackerspace allows for more curiosity-driven research, whereas academic scientists are constrained by funding opportunities. Patrik D'haeseleer, an RVC member and stalwart of the Bay Area DIYbio scene who works as a systems biologist at a national lab during the day, describes the biohackerspace as a "place to play," where he can explore things "they would never let me do at work," noting that there are scant opportunities to retrain in adjacent fields as a midcareer scientist.

${ }^{5}$ As if to illustrate her point, Stanford professor Drew Endy tweeted in 2014, "Is biotech only about tools, products, money, \& policy? Does homo ludens (culture of play) need to underlie homo faber (culture of making)?" 
Another RVC member, who worked in both academic and corporate labs, also presents biohacking as liberation from the constraints of these institutions, but interprets the difference in terms of ethical values rather than the hedonistic register of play and fun. This member found both prior workplaces to be "soul-sucking": academia for its rigid hierarchy, and the corporate world for putting "profit over people." This member was previously involved in Occupy Wall Street and later built on the experiences and personal connections he gained through RVC to found a startup company pursuing a closely related goal (he also advocated spinning out a startup company from RVC). When I asked, a year after our first conversation, if there was any unifying connection between his previous involvement with the Occupy movement, his participation in the DIYbio scene, and his efforts in the biotech startup sphere, he replied that the connecting thread was "autonomy." As he saw it, as a startup founder, he retained control of the company and he was confident and sincere in his desire and ability to make decisions that would do good in the world.

In each of these cases, biohacking is portrayed as superior because it is seen as removing restraints that are associated with large institutions, giving the freedom for human creativity to flourish. It is this characteristic that I mean to draw attention to in calling biohacking an "artistic critique" of the bioeconomy.

\section{Tensions Between the Artistic Critique and Critiques of Power and Inequality}

The sense of biohacking as free from restrictions, in the mode of the artistic critique, shapes the way in which tensions between competing understandings of concepts such as openness and decentralization are resolved. RVC was committed to "openness" from the start, but just how to enact openness, in a way that would be in keeping with the project's other goals and values, was not always clear. When the team discovered a startup taking a similar approach to create animalfree milk, RVC members were concerned that this company might patent parts of the process for producing milk proteins in yeast and prohibit RVC and others from continuing to work on the project. Thus, several options to secure the openness of the project were put on the table. The conversation was speculative, as it was not clear if any of RVC's results or methods so far were novel enough to be patentable; at the same time, it was highly informative about different ways in which participants imagined biohacking projects engaging with other social systems. In particular, the incident revealed how an approach that strives for the openness and the freedom from restrictions celebrated by the artistic critique can be in tension with one based on the desire for social justice, and attentive to the differential distribution of power in society.

The debate brought out tensions between the different principles driving the project, as well as how those principles were interpreted. Steven Levy's (2010) Hackers: Heroes of the Computer Revolution (first published in 1984) helped to codify the "hacker ethic" as several interrelated values, the enduring legacy of which is evidenced by the fact that the Wikipedia entry on "Hacker ethic" is printed and posted in the hallway leading to CCL. Decentralization, one of those enshrined values, is clearly central for RVC: graffiti at CCL blares the slogan “Decentralize all the things!" In Hackers, Levy presents bureaucratic centralization as an evil for 
hackers, because it puts barriers between individuals and tools or information. His example is IBM, in which "only the most privileged of priests would be permitted to actually interact with the computer" (n.p.).

An early proposal for dealing with the project's intellectual property reflected an understanding of the principle of decentralization that went beyond widening access to technology, as in Levy's description, and towards addressing the centralization of power in society: one member suggested that RVC could pursue a traditional patent, and then utilize discretion about how to share it. For example, RVC could license it free to non-profit groups or other scientific researchers, and charge a fee if a large company was interested. In the Occupyinfluenced setting of the Omni Collective, the larger building and organization housing CCL, this inflection of the principle of decentralization invokes opposition to economic structures that concentrate wealth and power in a small number of hands. With a goal of being the antiMonsanto, should the project practice a pure version of openness, making the work available to anyone-including those wealthy corporations who would already be best positioned to capitalize on it? Or should RVC sacrifice complete transparency, shielding some of the work from certain eyes, in order to push back against the structures that lead to the centralization of wealth and power, as some argued?

This first suggestion was quickly rejected since all three participating organizations (CCL, BioCurious, and RVC) were founded on principles of open source and open science; pursuing intellectual property rights and restricting access to the work, even if well intentioned, didn't fit with most people's understanding of openness. Instead, three proposals were finally put on the table. The first was to take no action other than publishing all lab work and data online, a practice that was already in place theoretically, if not always perfectly executed. A second suggestion offered by an intellectual property lawyer who chimed in via RVC's extensive email list was to "patent and abandon." This strategy involves filing a provisional patent to "stake a claim," thus bringing the project's work to the attention of the Patent and Trademark Office and decreasing the possibility that someone else would wrongly patent the same material. Then, the team would officially "abandon" the patent, putting it in the public domain. A third proposal involved a legal innovation called the Defensive Patent License (DPL), inspired by the GNU General Public License (GPL) (Schultz and Urban 2012). It works by creating a "patent pool"; any person or organization that joins the pool agrees to share all of the patents they hold with others in the pool, at no cost. Patents may still be enforced against others who are not in the pool.

Ultimately, the three propositions were put to a vote, and the second choice prevailed: the team would patent and abandon (following consensus-based decision-making practices, the option to go back to the drawing board if anyone strongly objected was held out, but this did not arise). The fear that pursuing the DPL would be costly and time-intensive was one reason that some members chose not to vote for it. Another rationale focused on the project's goal of pushing forward alternatives to animal-based agriculture; one member pointed out that if a large corporation were to adopt the technology, it could be a big step towards furthering the project's goals of mitigating environmental harm and animal cruelty. To the extent that the project is 
motivated by this latter goal, it is similar to other technology and product-oriented movements for which "private sector symbiosis" is a means of achieving goals (Hess 2005).

The decision to "patent and abandon" is also in line with the values of the artistic critique, minimizing any kind of restrictions on access and thus promoting a kind of negative liberty. The alternate suggestion to restrict access to some actors-as in the DPL or the original proposal to patent and license in a way that takes into account the status and intentions of the other party--is oriented more towards justice, addressing the differential distribution of power in society (corresponding with what Boltanski and Chiapello call the "social critique" of capitalism (38)). Yet most of the time, these ends were conflated, under the assumption that more openness would help facilitate a fairer distribution of power. As one member put it during the patenting discussion, "everything we are doing here"-referring to the work of establishing the biohackerspace and the RVC project itself, which had both been framed largely in terms of openness- "is against the centralization of power in the world." The patenting debate was one point at which a schism between promoting openness and addressing issues of power and inequality became apparent.

Underlying the conflation of these ends is the way in which the biohackerspace, like Brand's Whole Earth Catalogue decades earlier, serves as a "network forum" (Turner 2006, 73) in which countercultural, academic, and entrepreneurial cultures mingle. The messy assemblage of Bay Area biohacking derives from a number of different lineages which differently inflect biohacking's significance. In addition to connections with Maker culture (Tocchetti 2012) and the DIYbio network founded in Cambridge, MA, with participation from academic figures in synthetic biology (Roosth 2010), the tradition of European hacker collectives is another, more overtly political lineage that was present in the RVC ensemble-as was the Occupy movement, another influence especially apparent in CCL. These latter traditions in particular inflected the work at CCL with a social purpose beyond the well-known political concerns of many selfidentified hackers with free speech and civil liberties (Coleman 2013).

European hacklabs-which produced one of the earliest approaches to something like a citizen biotechnology in Critical Art Ensemble (CAE)'s “Free Range Grain" project (Delfanti 2013, 121) —are associated with the prefigurative politics of autonomous activist movements (Maxigas 2012), a praxis-based mode of politics that seeks to build alternatives to institutions of the state and capitalism (Fominaya 2014, 70). This mode of political action can be seen at the Omni Collective, where CCL is located. The Omni is a "collective of collectives": both a physical space in which other non-profits are located and an organizational process in which the groups work

"Chander and Sunder (2004) critique the "romance of the public domain," or the assumption underlying many progressive critiques of propertization that a resource "open to all by force of law" will be "equally exploited by all" (1331).

- Members of CCL are well aware of these different genealogies and what they signify. For example, during the initial organizing process for $\mathrm{CCL}$, as members were discussing naming, one (American) member wrote that she preferred not to use the term DIYbio, because it is "mostly an American term and not wellrecognized internationally," and also because "the website and brand are not run by a non-profit organization with community involvement." 
together to create and maintain that space as a public commons. Founders of the Omni have roots in Occupy Wall Street, and most of the organizations housed within share a commitment to creating ways of making, doing, and sharing that are outside the system of private property and profit; the Omni is explicitly countercultural and anti-capitalist (Mark 2015). As its name indicates, Counter Culture Labs partakes in this tradition.

Building on the tradition of prefigurative politics, groups at the Omni aim to build "counterinstitutions" as a mode of political action: alternative institutions that enact more democratic and egalitarian social relations while at the same time serving some instrumental function, such as helping to provide material necessities for life (Murray 2014). A counterinstitution "prefigures" a more egalitarian society on a small scale through its practices, and it also allows people to lessen their participation within systems seen as exploitative. Seen in the context of this tradition, the biohackerspace is a scientific counterinstitution, representing a more egalitarian and less hierarchical way of organizing scientific practices.

While this mode of politics converges with the artistic critique in its emphasis on autonomy from oppressive institutions, it also aims at a broader transformation of society, not secession. As the RVC member who advocated for the defensive patent license put it: "This isn't the 70's and we're not dropping out of society nor are we isolationists." This comment nods to the New Communalist wing of the counterculture that played an outsize role in the emergence of digital utopianism; the New Communalists split from the New Left in their rejection of agonistic politics in favor of transforming individual consciousness as a mode of social change (Turner 2006, 38).

Yet when considered within the larger political economy of biotechnology, the biohackerspace as a counterinstitution could, through policies of openness, be a "donation" (Delgado 2013, 72) of labor to private corporations. As strategies of "distributed innovation" have gained traction in the business world (Von Hippel 2005; Lakhani and Panetta 2007), companies are prepared to take advantage of innovations that arise outside their walls. Through the intermediary of a consulting group that described biohacking as an emerging trend in innovation, representatives of two large multinational companies that own many household food brands learned about the project and visited the labs to learn more. This interaction demonstrates that companies are poised to capitalize on technological developments in this realm should any arise. Moreover, because the work of the project is in the public domain, no special relationship would be required to take advantage of it, nor would the companies be required to contribute anything back to RVC, or to the knowledge commons that the project itself hoped to contribute to. While the biohackerspace, as a counterinstitution of science, is "other than" incumbent institutions, it can work with them in ways that benefit those institutions.

Finally, the hope that the biohackerspace, by way of being open to all, could represent a more egalitarian and inclusive counter-institution of science is somewhat undercut by data showing that DIYbio participants are more highly educated than the general population; a significant percentage have postgraduate training in science or engineering (Grushkin et. al 2013). These demographics carried over to RVC; one member estimated that there were at least $8 \mathrm{PhDs}$ who had contributed to the project in one way or another. Early participants, especially when the 
project was based out of the BioCurious in Silicon Valley, were generally representative of the tech industry's white-collar workforce (one difference was an over-representation of highly educated mothers, some with science PhDs, who had left full time work to take care of young children). Although CCL's current location in Oakland is accessible to a more ethnically and socioeconomically diverse crowd, there are obvious barriers to volunteering one's time in the evenings for individuals working multiple low wage jobs, or shouldering both working and caretaking responsibilities. CCL's organizational leadership is attentive to how structural inequality can impact accessibility and, for example, offers scholarships on membership fees. Still, as in the case of the patenting debate, the promotion of openness and freedom from constraints does not necessarily translate to actions that lessen social inequality, although many participants connected the imaginary of decentralized and accessible biotechnology with visions of social justice.

\section{Design and Desire: Creating Consuming Citizens}

The artistic critique is not primarily about art, but rather about liberating individual freedom and creative potential from the single-minded pursuit of capital accumulation represented by the large corporation and Fordist (or, in the case of biotechnology, monocultural) regime of conformity it is associated with. However, while art is not the only outlet for newly liberated creative energies, aesthetics can play a role in illustrating the departure from the previous regime. Dyson imagines that "designing genomes will be a personal thing, a new art form as creative as painting or sculpture," once biotechnology becomes "small and domesticated" rather than "big and centralized." Design fiction, for RVC and other biohacking and synthetic biology projects, is a key formal strategy for the articulation of the artistic critique: biohackers demonstrate, through the imagination of speculative products, what a more playful, creative, and liberated biotechnology practice could result in.

Like biohacking itself, design has been promoted as a way of democratizing new technologies (Dunne and Raby 2013, 49), as well as a way for synthetic biology to bridge the biological, technological, and social realms and take better account of the complex feedbacks between all three (Agapakis 2013). Designers as well as artists have been drawn to synthetic biology and design fiction has even been incorporated into public engagement activities (Halpern 2014). Design fiction often appears in iGEM projects, most successfully deployed by the grand prize-winning Cambridge team in 2009, whose collaboration with designers Daisy Ginsberg and James King resulted in a suitcase full of colorful (fake) poop illustrating how the team's pigmentproducing bacteria might be used in future probiotic home diagnostics.

Although RVC did not display a physical prototype at iGEM, the project's name and logo serve as a kind of design fiction. As Oryx and Crake's ChickieNobs illustrate, creating a brand name for a fictional product can help produce a "reality effect," suggesting embeddedness in our consumer world. Brand names are a special case of neologism, the coining of new words: a common device in science fiction, which paradoxically "conjure[s] up a sense of the inevitability of the new thing, or of a new discourse in which the neologism is embedded. If there is a word 
for it, it must already exist... Yet fictive neology also displays that it is fiction" (Csicsery-Ronay 2008, "First Beauty"). The project's name and the associated logo that appeared on the website, crowdfunding site, presentations, and social media accounts created to publicize the project constructed Real Vegan Cheese as a brand and gave it a sense of realness even though an edible product does not yet exist. The value of this branding work was evident in discussions about a potential RVC startup company, when it was suggested that the RVC non-profit could license the brand to the new company.

RVC, like other design fictions, inhabits the liminal space between the everyday and the magical and new. As a fictional object, it served as a seed around which future scenarios crystallize. Cyberpunk author and futurist Bruce Sterling writes that such fictional objects, or diegetic prototypes, help the viewer "suspend disbelief about change" (Bosch 2012). On the side of the "everyday," Real Vegan Cheese's name announces itself matter-of-factly, making it easy to imagine it on supermarket shelves. The project's website breathlessly announces Real Vegan Cheese in the present tense (a manner of describing the project echoed by news articles):

Real Vegan Cheese is a not a cheese substitute! It all starts with regular old baker's yeast. Through synthetic biology, we engineer our yeast to become milk-protein factories. Our milk proteins are then combined with water and vegan oil to make Vegan Milk which is ultimately converted into Real Vegan Cheese through standard cheese-making processes-just like cheese made from cow or goat milk! (https: / / realvegancheese.org/)

This introduction also uses a tactic common to the biotech industry, which normalizes genetic engineering by associating it with older agricultural techniques like selective breeding: this description highlights the use of "regular old baker's yeast" and "standard cheese-making processes."

At the same time, the project adds novelty by proposing not just regular cow cheese, but also narwhal cheese and human cheese, using the casein sequences specific to those species. While human cheese was chosen for its hypothesized potential to be less allergenic (and also sounds slightly grotesque, upping the attention-grabbing nature of the project), narwhal cheese adds a playful element to the moral appeals that promise a more humane and environmentally friendly method of production. Why narwhal? As Patrik explained, eliciting chuckles from the iGEM audience, "Because we can!...And if we can make narwhal cheese we are one step closer to making unicorn cheese!" This geeky-cool aesthetic earned the project accolades: "I'm sure synthetic biology can get weirder, but this is a great start," one approving journalist for O'Reilly media wrote, referencing Endy's exhortation to "keep synthetic biology weird" (Loukides 2014). Narwhal cheese adds an element of surprise and delight to the project that stands in contrast to the industrial feel that a synthetic food product could otherwise fall prey to. 


\section{Not Just a Summer Project!}

- This project goes well beyond iGEM - we're into

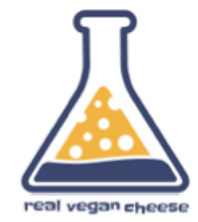
this for the long haul!

- We have set up a non-profit corporation.

- We raised $\$ 37,369$ in donations on Indiegogo - $\$ 10,000$ for a $50 \mathrm{~L}$ bioreactor for scaleup

- Narwhal Cheese!
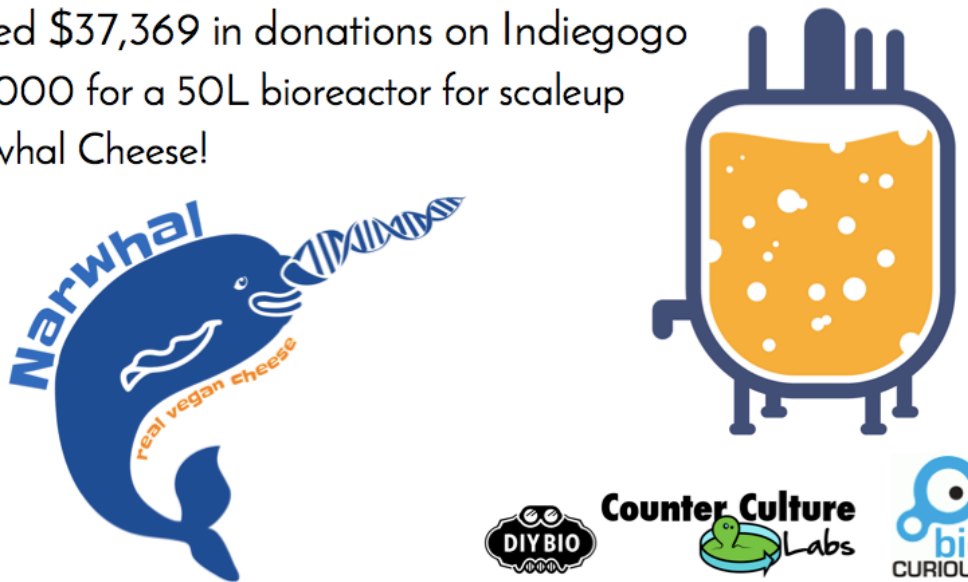

Counteg Culture

Fig. 1: A slide from the iGEM presentation

Speculative designers Dunne and Raby, who have been involved with synthetic biology, argue for the use of design fiction to promote critical engagement and democratization of biotechnology: "By presenting people with fictional products, services, and systems from alternative futures people can engage critically with them as citizen-consumers." Yet design, unlike bioart (which, the authors note, often comes across as "slightly gothic" (61)), aims to be aesthetically pleasing, and there can be a tension between engaging and seducing. Dunne and Raby note that the drawbacks of design as a method of engaging the public around new technologies include its potential facilitation of desensitization, acceptance, and opening of certain pathways that then become more likely for these first steps.

Kirby's 2010 discussion of diegetic prototypes provides some evidence for the idea that design fiction helps to normalize new technologies. Kirby shows that diegetic prototypes in film demonstrate the need for the technology as well as its benevolence and viability. Fictional technologies, or "diegetic prototypes," are embedded in the film's plot, and are made to seem both "ordinary and extraordinary" (10). The technologies are portrayed as plausible and even mundane within the fictional (diegetic) world, while simultaneously appearing futuristic to the viewer. These characteristics have made diegetic prototypes a useful tool for real-world technology developers, serving as a kind of "pre-product placement" that suggests such objects 
"can and should" exist (6). (Interestingly, this can be the case even when the technology is part of a dystopian world: one of Kirby's examples is the film Minority Report, which helped gain real world funding for the development of gestural interfaces.) Diegetic prototypes have moved beyond film to become increasingly popular tools for various groups interested in probing and shaping the future, from governments to companies (Bleecker 2009).

While the use of design fiction in synthetic biology can serve a valuable goal in imagining new uses for a technology and thinking creatively about how it may fit into different social worlds, it also helps to construct the public in a particular way. It often prompts engagement in the narrow form of consumer-citizenship, constructing a public that exerts political influence through purchasing power. Even as many designers hope to stimulate critical thought, their imagined products are constructed to seduce viewers. As Torgerson and Schmidt (2013) write about framing synthetic biology through analogy to information technology gadgets: "The public appears as potential consumers, on the one hand, and as enthusiast participants in the play that need to be taken on board" (51). Design fiction is a good tool for thinking about personal applications, products, and services, but less suited to more expansive global, or geopolitical visions of the future; for example, questions about global supply chains or the larger political economy of biotechnology are less likely to be foregrounded.

Involving designers in the field was a logical step for the synthetic biology industry at the time RVC was getting underway. The industry was pivoting from a focus on drugs, biofuels, and commodities such as rubber towards the areas of food and fragrances, in which consumer rejection posed one of the biggest risks (Hayden 2014). Many industry professionals were talking about the need to create compelling, consumer-friendly products. By marketing directly to consumers rather than intermediaries (such as farmers), it was hoped that the field could avoid the controversy that plagued GMOs. This viewpoint was in evidence at SynBioBeta, when Randal Kirk urged the audience to translate their work in synthetic biology into products and services that deliver "tangible value" to consumers to fight against "technophobia," a view that was echoed by other speakers at the conference. Kirk stated that "sociopolitical issues go away" when companies provide tangible value to consumers. Biohacking projects follow this same line of reasoning, where "tangible value" takes on a literal meaning: the public is invited not only to imagine holding a material product in their hands, but also to participate in the making of those products in the biohackerspace, or by purchasing DIYbio kits for home use. ${ }^{s}$

When considered as a mode of public engagement, then, RVC can be subject to similar critiques as those that have been levied against other kinds of public engagement exercises. Public engagement has been criticized for being one-sided, seeking to promote science and technology rather than allowing truly open-ended dialogue and outcomes (Wynne 2006). Thorpe and Gregory (2010) argue that this is not incidental but constitutive in the conditions under

\footnotetext{
"Antony Evans, founder of the crowdfunded Glowing Plant project, writes, "when people have genetically engineered organisms in their home they will build a real tangible relationship to the products and see for themselves how the anti-science propaganda is wrong." He urges the government to "encourage consumer biotech products because when consumers can touch and play with genetically engineered organisms they will learn to trust the technology" (blog.glowingplant.com).
} 
which public engagement has been promoted and supported by governments and funding agencies.' They understand public engagement exercises as connected to the increasingly active role that consumers play in shaping products as well as markets, and thus as a form of affective or immaterial labor (276). To an even greater degree, biohacking's artistic critique of biotechnology mobilizes not just a consuming public but one that might better be called "prosuming" (Ritzer and Jurgenson 2010) to reflect the active role that the public is invited to play in processes of production as well as consumption.

\section{Competing Legitimacy Claims}

In a discussion of the tensions between participatory means and various end goals of hacking, Powell writes, "legitimacy can be conferred through relationships to structures of authority but also-as all of the previous studies of hacking culture identify-through resistance to structures of authority" (2016, 6). The RVC project involved legitimacy appeals of both kinds, both associating and differentiating itself from structures of established scientific authority. Much of the rhetoric of the project constructs its legitimacy as a function of being outside institutions, driven by more authentic and ethical goals than the profit-driven corporation or the fundinghungry academic lab. The power of the "public" is another source of legitimation that resides outside institutions. RVC was able to claim an intimate level of engagement with that abstract but powerful entity; one of the team's iGEM slides proclaimed, "Public engagement approach: we ARE the public." In contrast, the team's very participation in iGEM was an effort to gain legitimacy through relation to constituted structures of authority.

iGEM participation can be read as a kind of legitimacy trade, in which the iGEM judges (most involved professionally with synthetic biology) read the project as a public validation of their field, while RVC members hoped for a positive evaluation at iGEM in order to support the scientific validity of the project (Meyer and Wilbanks 2017). While there are certainly tensions between these competing forms of legitimacy-not every RVC member wanted to participate in iGEM, and not every academic synthetic biologist welcomes the existence of biohackers, or thinks that bioengineering should be framed in terms of "play" - the relationship can be read as largely symbiotic, at least from the perspective of the "BioBricks vanguard" that has embraced the idea of biohacking. In somewhat contradictory ways, the biohacker--whether amateur or professional-mingles the traditional objective authority of science, the legitimating power of the public, and the renegade cool of the hacker whose "outsider" legitimacy is associated with

\footnotetext{
- Thorpe and Gregory argue that public engagement has been widely adopted precisely because of its promise to help create favorable conditions for post-Fordist economies: "public engagement enrolls participants into the formulation of those promissory futures and into the integration of these futures with existing social values and aspirations... The ideology of public engagement... is the late capitalist ideology of the innovation economy, in which individual consumer-citizens construct not only a market but also an innovation-ready society" (292-3).
} 
hedonism, playfulness, and personal authenticity. ${ }^{10}$ This figure is as much a creation of academic synthetic biologists as those outside institutions.

It is thus not entirely clear whether the mobilized public called into being by RVC and other biohacking publics should be considered an "official public," promoting a vision associated with incumbent institutions, or a "counterpublic," one that challenges incumbent institutions. The case of RVC supports the idea that upon closer inspection, idealized distinctions between publics and counterpublics give way to divisions among both elites and challengers (Hess 2016, 12). A robust DIYbio community helps to validate the BioBrick vanguard's promissory vision of biology made "easy to engineer," suggesting that this relatively recent approach deserves further funding and support. Meanwhile, the biohacking community includes both critics of the bioeconomy and those who want to open new markets for biotechnology products; it is not cohesive enough, and lacks the specific, oppositionally defined goals that would warrant the label of a social movement (Seifert 2015, 168). Instead, it aims to build capacities that would allow synthetic biology to be channeled towards new applications that are not incentivized in existing institutions: whether these be towards personal art projects, or cases of "undone science" (Hess 2016) such as the development of generic method of insulin production (as in CCL's Open Insulin project) or alternatives to animal agriculture.

Is biohacking, seen through the lens of project like RVC, a "technology of humility" (Jasanoff 2003) that leads to "a more resilient, democratic and experimental model for acting and decision making," as Kera argues $(2014,29)$ ? On the one hand, the biohackerspace does allow for upstream engagement with research and technology development. RVC may help drive synthetic biology's turn towards food applications and draw attention to the question of how synthetic biology could promote a more sustainable and humane food system, largely through channels of consumer-citizenship and entrepreneurship. The project's crowdfunding success is a signal to investors that these types of applications may find eager markets," and it remains possible that some members might form a startup to commercialize RVC. ${ }^{2}$ On the other hand, this type of engagement only involves those who want to develop and use the technology in some way and provides no means of engaging with those who want to avoid the development of a particular research program or technology.

In its least humble incarnations, biohacking mixes populist rhetoric with appeals to scientific objectivity and authority, and is not necessarily immune to scientism. Scientism can be

${ }^{10}$ Delfanti's 2013 analysis of biohacking characterizes it as a "remixing" of the modern science ethos with the hacker ethos, pointing out that both value systems appeal to autonomy in different ways (61). His analysis also shows how this remixing of cultures characterizes some professional biologists as well as DIYbio.

"Crowdfunding has been recognized for its legitimating function in the social entrepreneurship literature. Lehner and Nicholls (2014) write that it "may provide additional 'legitimacy' to the venture, as the crowd will select and support the social needs it deems worthy and thus create a strong investment signal to other players in the field"; they also note, "crowd-based processes may bring the additional benefit of being perceived as per se democratic" (275).

"As of July 2016, the team was discussing whether some members might form a RVC startup, what the relationship would be between the RVC non-profit corporation and the new company, and how a startup company could retain the "public benefit" orientation of the project (B-corporation and co-op models were discussed). 
defined as the reduction of contested social meanings to scientifically defined meanings (for example, framing questions about new technologies in terms of technical risk assessment) (Welsh and Wynne 2013, 553). For example, when Zayner was asked in an interview how he would respond to someone who was concerned about the risks of selling gene-editing kits online, he replied, "I would begin by asking the person, do you know what DNA is? And if they say no, then usually the conversation ends there (or if they struggle to explain it)" (Weissmueller 2016). This response disallows the possibility of objections that do not fit within a technically conceived notion of risk, as well as claims and subject positions that are rooted in non-scientific frameworks. In this respect, the artistic critique's celebration of autonomy, shored up by appeals to both popular and scientific authority, may be in tension with calls to democratize the governance of synthetic biology (Frow 2015), and could potentially impede dialogue with groups whose positions fall outside the boundaries of what biohackers determine to be scientifically legitimate. In this case, a conflation between science and technology can lend the authority of science to sociotechnical agendas. ${ }^{\mathrm{s}}$

CCL's ambition to be an organization with community buy-in does provide a mechanism for altering the course of projects based on the feedback of whoever shows up at meetings, but it remains to be seen how the deliberative and consensus-based practices of the biohackerspace would deal with more deeply divided factions. Regarding Friends of the Earth, an environmental group that opposes genetic engineering and has been highly critical of synthetic biology, some RVC members thought it was better not to engage with them at all, because the two groups have a fundamental disagreement about the facts of the matter. FOE's insistence that genetically engineered foods "can pose serious risks" to human bodies and the environment (http://www.foe.org/projects/food-and-technology/genetic-engineering) was seen by RVC members as an objectively false claim, since they consider the safety of GMOs to be a matter of settled science. The group was therefore seen as lacking legitimate standing to engage in deliberation.

The focus on autonomy that I have described as characteristic of the artistic critique in some ways harkens back to a "purist" view of science as obtaining legitimacy from its autonomy from utilitarian or profit-seeking motivations-ironically, reinstating an "ivory tower" view of science outside of the ivory tower. In this respect, biohacking can be read as a continuation of the "unbinding" of scientific authority from scientists that Moore (2009) describes in her analysis of scientist-led protest movements in the US after World War II. Moore notes, "although the authority of scientists to assert that they are neutral conduits for facts has weakened, public enthusiasm for 'scientific' claims more generally has not" (212-213). In the biohackerspace, scientific authority is dissociated from professional credentials.

${ }^{13}$ Conversely, the promise of technological innovation is also used to legitimize science; as Shapin puts it, "scientists and their paymasters work hard to identify science with technology, wanting nothing more than to have the authority of science supported by the utility of technology" [2015 n.p.]. While this conflation can involve rhetorical positioning, it also indexes increasingly intimate relations between academia and industry, science and technology, and a blurring of the underlying dichotomy between nature and society that underwrites the separation between pure and applied science, leading some scholars to adopt the term technoscience to refer to these hybrid endeavors (e.g., Haraway 1997, 3). 
At the same time, even though members of the DIYbio community sometimes frame opposition to GMOs as a matter of ignorance, the very nature of the project, which attempts to engineer a new social context for the production of biotechnology, dovetails with research that shows public ambivalence about biotechnologies is not due to ignorance but rather to concerns about the actors involved and the contexts in which it is developed (Marris 2001). In this respect, it moves beyond the deficit model, in which an ignorant public needs to be educated to get on board with new technologies, towards addressing the social context of technology development as a legitimate concern.

Biohacking projects mobilize the legitimizing power of their publicness (in the sense that they describe themselves as grassroots, open to all, and acting in the public interest) in order to convince an imagined skeptical and/ or fearful public of the benefits of synthetic biology. They offer opportunities for non-scientists to intervene in the upstream development of synthetic biology applications, insofar as these participants support some kind of development of the technology in the first place. Finally, they contribute to the construction of a different kind of scientific authority, one that merges renegade hacker cool with the traditional persona of the scientist as a disinterested and objective observer. Critiquing the institutions of Big Bio, they intervene in the affect and aesthetics of biotechnology in the hopes of mobilizing a public of biotech prosumers: an outcome that would be welcomed by many of those same institutions.

\section{Author Biography}

Rebecca Wilbanks is a doctoral candidate in Stanford's Program in Modern Thought and Literature, where her research explores the intersections between science, literature, and culture. Her dissertation, "Synthetic Biology and Life's Imagined Futures," argues that narrative frameworks from science fiction are crucial to understanding how efforts to engineer life are unfolding today.

\section{Acknowledgements}

The author would like to acknowledge writing seminar participants at the Stanford Center for Biomedical Ethics, an anonymous peer reviewer, the editors of ESTS, Katie Vann and Daniel Lee Kleinman, and Ursula Heise for helpful feedback on earlier versions of this paper.

\section{References}

Agapakis, Christina M. 2013. “Designing Synthetic Biology." ACS Synthetic Biology 3 (3): 121-28. doi:10.1021/sb4001068.

Atwood, Margaret. 2004. Oryx and Crake. Virago Press.

Bensaude Vincent, Bernadette. 2016. "The Moral Economy of Synthetic Biology." In Synthetic Biology, edited by Joachim Boldt. Wiesbaden: Springer Fachmedien Wiesbaden. http:/ / link.springer.com/10.1007/978-3-658-10988-2. 
Bleecker, Julian. 2009. “Design Fiction: A Short Essay on Design, Science, Fact, and Fiction." Near Future Laboratory.

Boltanski, Luc, and Eve Chiapello. 2005. The New Spirit of Capitalism. Verso.

Bosch, Torie. 2012. "Sci-Fi Writer Bruce Sterling Explains the Intriguing New Concept of Design Fiction." Slate, March 2. http:/ / www.slate.com/blogs/future_tense/2012/03/02/bruce_sterling_on_design_ficti ons_.html.

Calvert, Jane. 2013. "Collaboration as a Research Method? Navigating Social Scientific Involvement in Synthetic Biology." In Early Engagement and New Technologies: Opening up the Laboratory, edited by Neelke Doorn, Daan Schuurbiers, Ibo van de Poel, and Michael E. Gorman, 16:175-94. Dordrecht: Springer Netherlands. http:/ / link.springer.com/10.1007/978-94-007-7844-3_9.

Chander, Anupam, and Madhavi Sunder. 2004. "The Romance of the Public Domain." California Law Review, 1331-1373.

Coleman, E. Gabriella. 2013. Coding Freedom: The Ethics and Aesthetics of Hacking. Princeton University Press.

Collins, Harry M., and Robert Evans. 2002. "The Third Wave of Science Studies of Expertise and Experience." Social Studies of Science 32 (2): 235-296.

Csicsery-Ronay Jr., Istvan. 2008. The Seven Beauties of Science Fiction. Kindle edition. Wesleyan University Press.

Delfanti, Alessandro. 2013. Biohackers: The Politics of Open Science. London: Pluto Press.

Delgado, Ana. 2013a. “DIYbio: Making Things and Making Futures." Futures 48 (April): 65-73. doi:10.1016/j.futures.2013.02.004.

Delgado, Ana, and Blanca Callén. 2016. "Do-It-Yourself Biology and Electronic Waste Hacking: A Politics of Demonstration in Precarious Times." Public Understanding of Science, 963662516647348. doi:10.1177/0963662516647348.

Dunne, Anthony, and Fiona Raby. 2013. Speculative Everything: Design, Fiction, and Social Dreaming. MIT Press.

Dyson, Freeman. 2007. "Our Biotech Future." The New York Review of Books, July 19. http:/ / www.nybooks.com/articles/2007/07/19/our-biotech-future/.

Endy, Drew. 2014b. "Is Biotech Only about Tools, Products, Money, \& Policy? Does Homo Ludens (Culture of Play) Need to Underlie Homo Faber (Culture of Making)?" September 18. https: / / twitter.com/drewendy/status/512638461900103680.

Etzioni, Amitai, and Clyde Nunn. 1974. "The Public Appreciation of Science in Contemporary America." Daedalus 103 (3): 191-205.

Etzkowitz, Henry. 2003. “Research Groups as 'quasi-Firms': The Invention of the Entrepreneurial University." Research Policy 32 (1): 109-21. doi:10.1016/S0048-7333(02)00009-4.

Fominaya, Cristina Flesher. 2014. Social Movements and Globalization: How Protests, Occupations and Uprisings Are Changing the World. Basingstoke and New York: Palgrave Macmillan. 
Frow, Emma. 2015. "Rhetorics and Practices of Democratization in Synthetic Biology." In Knowing New Biotechnologies: Social Aspects of Technological Convergence. New York: Routledge.

Grushkin, Daniel, Todd Kuiken, and Piers Millet. 2013. "Seven Myths and Realities about Do-ItYourself Biology." 5. Synbio. Woodrow Wilson Center.

Halpern, Megan. 2014. "Design Fiction as Public Engagement with Synthetic Biology." Workshop on Research Agendas in the Societal Aspects of Synthetic Biology. Tempe, AZ.

Haraway, Donna Jeanne. 1996. Modest-Witness@Second-Millennium.FemaleMan-Meets_OncoMouse: Feminism and Technoscience. New York: Routledge.

Hayden, Erika. 2014. "Synthetic-Biology Firms Shift Focus." Nature 505 (7485): 598-598. doi:10.1038/505598a.

Helmreich, Stefan. 2009. Alien Ocean: Anthropological Voyages in Microbial Seas. University of California Press.

Hess, D. J. 2005. “Technology- and Product-Oriented Movements: Approximating Social Movement Studies and Science and Technology Studies." Science, Technology E Human Values 30 (4): 515-35. doi:10.1177/0162243905276499.

Hess, David J. 2016. Undone Science: Social Movements, Mobilized Publics, and Industrial Transitions. MIT Press.

Hilgartner, Stephen. 2015. "Capturing the Imaginary: Vanguards, Visions, and the Synthetic Biology Revolution." In Science and Democracy: Making Knowledge and Making Power in the Biosciences and Beyond, edited by Stephen Hilgartner, Clark Miller, and Rob Hagendijk. Routledge.

Irani, Lilly. 2015. "Hackathons and the Making of Entrepreneurial Citizenship." Science, Technology \& Human Values, April, 162243915578486. doi:10.1177/ 0162243915578486.

Irwin, Alan. 2006. "The Politics of Talk: Coming to Terms with the 'New' Scientific Governance." Social Studies of Science 36 (2): 299-320. doi:10.1177/ 0306312706053350.

Jasanoff, Sheila. 2003. "Technologies of Humility: Citizen Participation in Governing Science." Minerva 41: 223-44.

Kelty, Christopher. 2010. “Outlaw, Hackers, Victorian Amateurs: Diagnosing Public Participation in the Life Sciences Today." Jcom 9 (1).

—_ 2013. "From Participation to Power." Participatory Cultures Handbook, ed. Aaron Delwiche and Jennifer Henderson. Routledge.

Kelty, Christopher, and Aaron Panofsky. 2014. “Disentangling Public Participation In Science and Biomedicine." Genome Medicine 6 (8).

https: / / genomemedicine.biomedcentral.com/articles / 10.1186/gm525.

Kera, Denisa. 2014. "Innovation Regimes Based on Collaborative and Global Tinkering: Synthetic Biology and Nanotechnology in the Hackerspaces." Technology in Society 37 (May): 28-37. doi:10.1016/j.techsoc.2013.07.004.

Kirby, D. 2010. “The Future Is Now: Diegetic Prototypes and the Role of Popular Films in Generating Real-World Technological Development." Social Studies of Science 40 (1): 4170. doi:10.1177/0306312709338325. 
Knorr-Cetina, Karin D. 1984. "The Reappropriation of Technology." In Alteration in Food Production, edited by Dietrich Knorr and Tom Watkins. London: Van Nostrand Reinhold. https: / / kops.uni-konstanz.de/handle/123456789/11413.

Kohlenberger, Judith. 2015. The New Formula For Cool: Science, Technology, and the Popular in the American Imagination. Bielefeld: transcript Verlag.

Krimsky, Sheldon. 2004. Science in the Private Interest: Has the Lure of Profits Corrupted Biomedical Research? Rowman \& Littlefield.

Lakhani, Karim R., and Jill A. Panetta. 2007. "The Principles of Distributed Innovation." Innovations 2 (3): 97-112.

Landrain, Thomas, Morgan Meyer, Ariel Martin Perez, and Remi Sussan. 2013. "Do-It-Yourself Biology: Challenges and Promises for an Open Science and Technology Movement." Systems and Synthetic Biology 7 (3): 115-26. doi:10.1007/s11693-013-9116-4.

Lehner, Othmar M., and Alex Nicholls. 2014. "Social Finance and Crowdfunding for Social Enterprises: A Public-private Case Study Providing Legitimacy and Leverage." Venture Capital 16 (3): 271-86. doi:10.1080/13691066.2014.925305.

Levy, Steven. 2010. Hackers: Heroes of the Computer Revolution - 25th Anniversary Edition. O'Reilly Media, Inc.

Loukides, Mike. 2014. "Designing Real Vegan Cheese." O'Reilly Radar. July 17. http:/ / radar.oreilly.com/2014/ 07/ designing-real-vegan-cheese.html.

Mark, Julian. 2015. "Radically Sharing Temescal." East Bay Express, January 21. http:/ / www.eastbayexpress.com/oakland/radically-sharingtemescal / Content?oid=4172033.

Marris, Claire. 2001. "Public Views on GMOs: Deconstructing the Myths." EMBO Reports 2 (7): 545-48. doi:10.1093/embo-reports/kve142.

—_ 2015. "The Construction of Imaginaries of the Public as a Threat to Synthetic Biology." Science as Culture 24 (1): 83-98. doi:10.1080 / 09505431.2014.986320.

Maxigas. 2012. "Hacklabs and Hackerspaces - Tracing Two Genealogies." Journal of Peer Production, no. 2 (June).

Meyer, Morgan, and Rebecca Wilbanks. 2017. "Entre le garage, le public et le marché : valuations de la biologie do-it-yourself." In Savants, artistes, citoyens: tous créateurs?, edited by Olivier Leclerc, Editions Sciences et biens communs, Québec.

Moore, Kelly. 2008. Disrupting Science: Social Movements, American Scientists, and the Politics of the Military, 1945-1975. Princeton University Press.

Murray, Daniel. 2014. "Prefiguration or Actualization? Radical Democracy and CounterInstitution in the Occupy Movement." Berkeley Journal of Sociology, November. http:/ / berkeleyjournal.org/2014/11/ prefiguration-or-actualization-radical-democracyand-counter-institution-in-the-occupy-movement/.

Nowotny, Helga, Peter Scott, and Michael Gibbons. 2003. "Introduction: Mode 2 revisited: The New Production of Knowledge." Minerva 41 (3): 179-194.

Powell, Alison. 2016. "Hacking in the Public Interest: Authority, Legitimacy, Means, and Ends." New Media \& Society 18 (4): 600-616. 
Rappaport, Joanne. 2008. "Beyond Participant Observation: Collaborative Ethnography as Theoretical Innovation." Collaborative Anthropologies 1 (1): 1-31. doi:10.1353/ cla.0.0014.

Rip, Arie. 1986. "Legitimations of science in a changing world." In Wissenschaftssprache und Gesellschaft : Aspekte der wissenschaftlichen Kommunikation und des Wissenstransfers in der heutigen Zeit, edited by Bungarten, Theo, 133-48. Edition Akademion. http:/ / purl.utwente.nl/ publications / 57109.

Ritzer, George, and Nathan Jurgenson. 2010. "Production, Consumption, Prosumption The Nature of Capitalism in the Age of the Digital 'prosumer.'" Journal of Consumer Culture 10 (1): 13-36.

Roosth, Sophia. 2010. "Crafting Life: A Sensory Ethnography of Fabricated Biologies." Massachusetts Institute of Technology.

Schmandt, Jurgen. 1971. "Crises and Knowledge." Science 174 (4006): 231-231. doi:10.1126/science.174.4006.231.

Schultz, Jason, and Jennifer M. Urban. 2012. “Protecting Open Innovation: The Defensive Patent License as a New Approach to Patent Threats, Transaction Costs, and Tactical Disarmament." Harv. JL \& Tech. 26: 1.

Seifert, Franz. 2015. "Converging Technologies and Critical Social Movements: An Exploration." In Knowing New Biotechnologies: Social Aspects of Technological Convergence. New York: Routledge.

Shapin, Steven. 2015. "The Virtue of Scientific Thinking." Boston Review, January 20. https: / / bostonreview.net/ steven-shapin-scientism-virtue.

Stokes, Donald E. 1997. Pasteur's Quadrant: Basic Science and Technological Innovation. Washington, D.C.: Brookings Institution Press.

Suchman, Mark C. 1995. "Managing Legitimacy: Strategic and Institutional Approaches." The Academy of Management Review 20 (3): 571. doi:10.2307 / 258788.

Thorpe, Charles, and Jane Gregory. 2010. "Producing the Post-Fordist Public: The Political Economy of Public Engagement with Science." Science as Culture 19 (3): 273-301. doi:10.1080/09505430903194504.

Tocchetti, Sara. 2012. “DIYbiologists as 'Makers' of Personal Biologies: How MAKE Magazine and Maker Faires Contribute in Constituting Biology as a Personal Technology." Journal of Peer Production 2: 1-9.

Tocchetti, S., and S. A. Aguiton. 2015. "Is an FBI Agent a DIY Biologist Like Any Other? A Cultural Analysis of a Biosecurity Risk." Science, Technology \& Human Values 40 (5): 82553. doi:10.1177/0162243915589634.

Torgersen, Helge, and Markus Schmidt. 2013. "Frames and Comparators: How Might a Debate on Synthetic Biology Evolve?" Futures 48 (April): 44-54. doi:10.1016/j.futures.2013.02.002.

Turner, Fred. 2006. From Counterculture to Cyberculture: Stewart Brand, the Whole Earth Network, and the Rise of Digital Utopianism. University of Chicago Press.

Upton, John. 2013. "As World Marches against Monsanto, Senators Protect It from Labeling Laws." Grist, May 27. http://grist.org/food/as-world-marches-against-monsantosenators-protect-it-from-labeling-laws/. 
Vallas, S. P., and D. L. Kleinman. 2008. "Contradiction, Convergence and the Knowledge Economy: The Confluence of Academic and Commercial Biotechnology." Socio-Economic Review 6 (2): 283-311. doi:10.1093/ser/mw1035.

Von Hippel, Eric. 2005. "Democratizing Innovation: The Evolving Phenomenon of User Innovation." Journal Für Betriebswirtschaft 55 (1): 63-78. doi:10.1007/ s11301-004-0002-8.

Warner, Michael. 2002. "Publics and Counterpublics." Public Culture 14 (1): 49-90.

Weissmueller, Zach. 2016. "Is Unregulated Biohacking the Future of Science? Interview with Josiah Zayner." Reason.com, June 20. http:/ / reason.com/reasontv/2016/06/20/ biohacking-the-genome-for-just-140.

Welsh, Ian, and Brian Wynne. 2013. "Science, Scientism and Imaginaries of Publics in the UK: Passive Objects, Incipient Threats." Science as Culture 22 (4): 540-66. doi:10.1080/14636778.2013.764072.

Winickoff, David E. 2013. "Private Assets, Public Mission: The Politics of Technology Transfer and the New American University." Jurimetrics 54 (1). http:/ / papers.ssrn.com/sol3 / papers.cfm?abstract_id=2316996.

Wohlsen, Marcus. 2011. Biopunk: Solving Biotech's Biggest Problems in Kitchens and Garages. Penguin.

Wynne, Brian. 2006. "Public Engagement as a Means of Restoring Public Trust in Science Hitting the Notes, but Missing the Music?" Public Health Genomics 9 (3): 211-20. doi:10.1159/000092659.

Ziman, John. 2000. Real Science: What It Is and What It Means. Cambridge, UK: Cambridge University Press. 